\title{
Civil law obligation reform in Russian Federation and its effect on the institute of damages (losses)
}

\author{
Yu.E.Monastyrsky ${ }^{1}$, V.N. Koval ${ }^{2}$, A. A. Vlasov ${ }^{1}$ \\ ${ }^{1}$ Moscow State Institute of International Relations, \\ 76, pr. Vernadskogo, Moscow, 119454, Russian Federation \\ ${ }^{2}$ Higher Attestation Commission of Ministry of Education and Science of Russian Federation, \\ 51, Liusinovskaia ul., Moscow, 115093, Russian Federation
}

For citation: Monastyrsky, Yuri E., Vladimir N. Koval', Anatoliy A. Vlasov. 2021. "Civil law obligation reform in Russian Federation and its effect on the institute of damages (losses)". Vestnik of Saint Petersburg University. Law 3: 574-583. https://doi.org/10.21638/spbu14.2021.306

When an economic actor resorts to recovery of damages as a legal remedy, the main question that arises is what legal provisions govern the claim raised by such an actor. At a first glance, the answer is simple: both Chapter 25 ("Liability for violation of obligations") and Article 15 ("Reimbursement of damages") of the Civil Code of the Russian Federation contain provisions governing the terms of satisfaction of financial claims. However, such claims do not always arise from a failure to perform obligations and sometimes are even raised in the absence of an offence per se as stated by law. Therefore, quite often we need to consider the extent to which it would be lawful or, perhaps, even appropriate to invoke some of the provisions contained in Subsection 1 "General provisions on obligations" of Section III of the Civil Code. More detailed provisions on obligations introduced in March 2015 to Civil Code of RF may not be compatible with circumstances of losses. Articles 310, 311, 313, 314, $328,407,416$ if applicable to damages recovery claims would undermine the said remedy as such. They grand a debtor the legal basis assumed and adopted as his limited protection in obligatory relationship as a whole to avoid the burden of full reimbursement by suspension of performance, counter demands, etc.

Keywords: civil law, liability, damages, loss, fault, harm, obligation.

\section{Introduction}

Settlement of obligations and recovery of damages laws have long been viewed as lex generalis and lex specialis. The latter is a part of the former in the prerevolutionary Russian civil law doctrine. The consolidated laws of the Russian Empire up to 1917 consisted of thirty-three volumes and contained only three basic provisions on "remuneration for harm and damages". Prominent theoreticians stated that "not allowed" detrimental acts create an obligation subject to immediate discharge.

During the Soviet period, scholars equally supported both the obligational and nonobligational nature of losses. The most popular assertion was that a failure to perform obligations in a contractual relationship leads to an appearance of ancillary or supplementary obligations. In the area of torts, it was firmly understood that any diminution of property had an effect of a new obligation to compensate it in full unless otherwise provided for by law.

(c) St. Petersburg State University, 2021 
A new detailed and structured Civil Code was adopted in $1994^{1}$ with an extensive regulation of obligations apart from legal duties as a whole. The underlined objectives of ensuring better protection for property rights as valuables and, in principle, certain sellable property can be seen from the Civil Code provisions supporting creditors. Six chapters and one hundred forty-eight articles were devoted to the discharge, turnover, and assignment of claims to perform obligations; and it became apparent that the same is expressis verbis irrelevant as a whole to claims to recover damages which may hardly be considered as valuables.

The notion of obligations better detailed in the Civil Code leaves less doubts that they are much less identical to duties from damages. Damages themselves do not create a duty to fulfill a pecuniary obligation; they must have a different legal status. On the other hand, certain well-known civil law securities like suretyship are not only compatible with demands to recover damages but are required for them.

Certain areas of the banking sector rest on trade and assignments of monetary claims irrespective of their source. Hence, definite legal provisions regulating at least the replacement of creditors are necessary. As a result, it is essential to decide what would be the optimal correlation between the rules of Section III of the Civil Code (which apply to recovery of damages), provisions on obligations in the Civil Code.

In this article the authors have used the induction-based approach by pinpointing a number of new provisions in the Civil Code unrelated to claims of losses in five chapters of its Subsection I ("General provisions of obligations") and II ("General provisions on contract"). They then made a generalization as to the scope of application of the chapters.

The authors have arrived at conclusive results that the logic of a more detailed regulation of obligations made the whole corps of legislation inapplicable to settlement of demands for damages. New amendments are recommended for the following chapters of the Civil Code - to the chapter on the replacement of persons in obligations and applicable also to the assignment of damages recovery claims.

Earlier, the issue of the legal nature of a damages recovery claim was not analyzed in much detail. In the EU model, rules obligations are derived from the conclusion of contracts only and unrelated to torts and unlawful acts. This article comments on this feature. The authors have used some of European sources to confirm certain legal positions.

\section{Basic research}

\subsection{Application of chapter 21 "Notion of obligation" of the Civil Code to recovery of damages}

In Russian and international (Hesselink 2001) legal discourse, we deal with the application of the fundamental concepts of duty and obligation as synonyms. Some publications may even be found to use the wording "fiscal obligation" and "protective obligation"

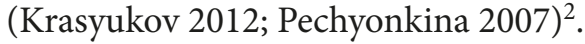

${ }^{1}$ Hereinafter all Russian laws, statutory instruments, and court rulings are given in connection with the inquiry system "ConsultantPlus". Accessed December 20, 2019. http://www.consultant.ru.

2 Similar examples of the use of that wording are also found in RF Supreme Court Ruling No. 307ES19-8719 dated 6 August 2019 in case No. A56-44788/2018, RF Supreme Court Judicial Chamber on Administrative Cases Ruling No. 5-KA19-1 dated 28 March 2019, etc. 
The regulatory differentiation between an obligation and a duty is implemented, for example, in Article 420 of the Civil Code. At first it is established that a contract constitutes an agreement as to rights and duties, and Paragraph 3 of the same article provides that obligations arising out of a contract shall be subject to general and special provisions of the Civil Code. The semantic interpretation of these provisions is as follows: a contract also governs duties that neither constitute obligations nor consist in "specific actions", and it is really so (Agarkov 1940, 14-15).

Article 8 Grounds for Arising of Civil Rights and Duties of the Civil Code sets out, inter alia, the following reasons: events, court decisions, creation of intellectual property or property acquisition. However, the Civil Code establishes a legal framework to delineate the two aforementioned terms. Article 307 sets forth:

1. By virtue of an obligation, one person (the debtor) shall be obliged to take a specific action in favour of another person (the creditor) such as transfer a property, perform a job, provide a service, contribute to a joint activity, pay an amount of money, etc. or abstain from taking a certain action, and the creditor shall have the right to claim that the debtor should perform his duty.

2. Obligations may arise out of agreements or other deals, from the infliction of damage (Koziol 2012, 406) as a result of unjustified enrichment... or for any of the other reasons set out in this Code.

3. $\langle\ldots\rangle$ the parties shall act in good faith while taking into account the rights and legitimate interests of each other and mutually assisting each other as may be necessary to reach the intended purpose of such obligation and providing each other with any necessary information.

Therefore, the grounds for the creation of obligations may only be set out in the Civil Code and nowhere else. If interpreted teleologically, Article 307 (3) essentially states that the main characteristic of an obligation is the proposed uniform understanding of the essence, scope, size, terms and purpose thereof by the parties to such obligation, giving an idea of how the parties should co-operate in reaching that purpose (Agarkov 1940). Keeping those parameters in mind, the parties to an obligation tend to differ from participants in the recovery of damages. The damages debtor will always tend to either deny the amount claimed or agree to a smaller amount. Under the applicable law, such claims may be for any future expenses, earnings of the offending party or the cost of any arrangements it is expected to make; the claims may from time to time be either increased or decreased (Sadikov 2009, 30-31).

The concept of an obligation, which had originally appeared as a legal instrument and a substantive legal remedy, subsequently strengthened by institutional methods of securing performance such as pledge, penalty, suretyship, lien, guarantee or security payment, has now become an important commercial valuable itself and the main transferrable item taking the form of rights to claim performance of obligations. An obligation is a material benefit that saw the volume of transactions therewith increase hundreds of times during the recent years. Whereas at the dawn of human civilisation, almost always people disposed of material objects by exchanging them (Novitsky 1993, 176).

An obligation may be subject to any additional conditions: subsequent, precedent, etc. (Article 157 of the Civil Code). 
Estimated damages are the cost of a subjective right infringement (Meyer 1997, 216; Pobedonostsev 1896, 589; Agarkov 1940, 40) by any act which may be unlawful or lawful (Sadikov 2009, 12-16; Pokrovsky 1998, 275). Articles 307 and 1082 of the Civil Code state that the infliction of harm or a tort shall give rise to an obligation to reimburse such harm or a tort by replacing or restoring the demolished property or repairing the defect. When a property-related subjective right is infringed, neither the creditor nor the debtor may be said to have obtained any value in the form of a right to claim. The relationships arising in this case essentially constitute the monetization and the payment of cost of unfulfilled expectation (Sadikov 2009, 120-121) where the only existing duty is not to aggravate losses and the recovery of damages may not be waived in advance.

The recovery of damages plays the role of an alternative legal remedy (Novitsky, Lunts 1950, 293) (Article 1082 of the Civil Code). According to Principles of European Tort Law $(2002)^{3}$, the infliction of damages immediately gives rise to liability in the form of a duty to affect payment in order to restore, to the maximum extent possible, the aggrieved party's initial monetary state 4 . However, instead of such a monetary duty, the aggrieved party may claim recovery in kind, provided that such recovery is possible and is not too burdensome for the other party ${ }^{5}$.

The differentiation between obligations and duties to pay damages appear to be inevitable and pre-determined by the regulatory logic. Efforts to determine the value of an obligation are rarely prone to a disagreement. The "specific action", which constitutes the essence of an obligation under Article 307 of the Civil Code, suggests a uniform understanding of its ideal characteristics. In contrast to it, complaints over proper performance cause disputes over losses and are almost always controversial. Damages must depend on creditor behaviour aimed at mitigating consequences. Their existence, nature, structure and essence are to be proven. Economically, that could not but result in the relevant rights being treated differently. On the contrary, expectations to benefit from obligations should be left free floating and strengthened by the safeguarding mechanisms of consideration, security and facilitated transfer expressed in the concepts of future right assignment, absence of additional transfer formalities, etc.

The Civil Code clarifies that the purpose of performance of obligations shall be understood uniformly (Article 307 (3) of the Civil Code), assuming mainly that its amount is understandable and it is static, determinable, very reliable in terms of discharge of such obligations and co-operation and would sometimes be hard to implement if no such cooperation is provided.

No liability claims may be identical if only because they result from the lopsided approach to their cost, lawfulness and legality and the appropriate measures to be taken to decrease the underlying losses. No security method is applicable here without limitation, as such unlimited application would raise the question as to their legal existence because of the accessory nature immanent to them (Article 329 (4) of the Civil Code). That said, where a failure to perform an obligation unilaterally translates into a duty to pay damages,

${ }_{3}$ Principles of European Tort Law. 2005. Accessed December 25, 2019. http://www.egtl.org/docs/ PETL.pdf.

${ }^{4}$ Principles of European tort law, Art. 10:101. Nature and purpose of damages. - "Damages are a money payment to compensate the victim, that is to say, to restore him, so far as money can, to the position he would have been in if the wrong complained of had not been committed".

${ }^{5}$ Principles of European tort law, Art. 10:104. Restoration in kind. - "Instead of damages, restoration in kind can be claimed by the injured party as far as it is possible and not too burdensome to the other party". 
security instruments are indispensable. It would be advisable to amend Chapter 23 of the Civil Code so as to prescribe that binding support and security mechanisms should be applied to claims for losses, but not to all of them and only to the extent that they are compatible with each other. This is addressed in greater detail further on in the article.

Russian courts have not yet managed to come to a uniform conclusion that Article $328^{6}$ of the Civil Code may not apply to those relationships. However, as far as the authors are aware, some of Russia's leading legal scholars are quite confident that a breach of an agreement will give rise to an obligation subject to the legal treatment prescribed by Section III of the Civil Code (Sadikov 2009, 27; Sarbash 2016, 251). Notionally, it may well be so as claims to perform obligations are known to be capable of assignment, by way of subrogation to insurers, etc.

It was the obligations to "remunerate for any harm or damages"7 that Russian distinguished legal scholars such as V. I. Sinaisky (Sinaisky 2002, 36), I. A. Pokrovsky (Pokrovsky 1998, 274-294) and K. P. Pobedonostsev (Pobedonostsev 1896, 274-294) wrote about in the $19^{\text {th }}-$ beginning of the $20^{\text {th }}$ centuries. M. M. Agarkov, a well-known Soviet civil law scholar, said that a claim for loss was legally binding for a debtor under ancillary obligation (Agarkov 1940, 24-25).

We believe it was true under the laws that existed in the Soviet era. However, at present, especially in light of the 8 March 2015 amendments, the regulation of obligations has been considerably detailed and at least not all rules of law may apply to the recovery of damages.

\subsection{Admissible legal influence of chapter 22 "Performance of obligation" of the Civil Code}

Let us consider the applicability of Chapter 22 of the Civil Code regarding claims for losses. The new wording of Article 310 of the Civil Code permits grounds for refusal by a commercial entity to perform its obligations under a contract to be stipulated in advance. If Article 310 of the Civil Code covered losses, it would imply a waiver of rights and make it legally possible to pre-agree on the avoidance of liability even for gross negligence (Article 401 (4) of the Civil Code prohibits any release in full or in part from liability for malicious intent) - a development that would undermine the concept of damages and result in its importance being diminished.

Article 311 of the Civil Code says that the creditor may refuse to accept partial performance of an obligation, i.e., any disagreement on the total amount of losses would constitute a reason not to accept performance, thereby further aggravating the delay. "The creditor may refrain from accepting partial performance of an obligation, unless other-

6 See, e. g., clause 17 of RF Supreme Court Presidium Information Letter No. 120 dated 30 October 2007 titled "Review of the practical application of Commercial Courts of the Provisions of Chapter 24 of the Civil Code of the Russian Federation" where the RF Supreme Court expressly calls them "obligations"; also see RF Supreme Court Ruling dated No. 304-ES18-23140 22 January 2019 in case No. A46-7338/2017, RF Supreme Court Judicial Chamber on Economic Disputes No. 307-ES17-14888 dated 22 December 2017 in case No. A21-8181/2016, etc.

7 The wording "compensate for any harm or damage" was officially set out in Article 684 of the Code of Laws of the Russian Empire (The Code of Laws of the Russian Empire. Accessed November 20, 2019. http://www.pravo.gov.ru/proxy/ips/?empire\&nochache). 
wise prescribed by law, other legal acts or the terms of such obligation", and such partial performance may be rejected in full.

If claims for losses constitute a demand to fulfil an obligation, such obligation is a financial one ${ }^{8}$. It is also worth noting that Article 313 of the Civil Code provides that the discharge of a monetary obligation by a third party would mean subrogation and could cause chaos in the domain of damages cases as it would legitimise the involvement of a third party who has paid the losses in full and begins claiming the same from the debtor. Unlike contractual assignment, which is conditioned on a considerable discount off the par value of the claim, while the size and configuration of the claim remain unchanged, typically disputable nature of damages would make that transaction economically unfeasible and could easily induce abuses and arbitrary behaviour of the powerful party (Yegorov 2016; Frolova 2017).

When a notification triggering limitation period is not made at all, resulting in no applicable period of limitation beginning to elapse, such claims are eternal - an outcome hardly envisaged by the legislators (Article 314 (2) of the Civil Code). Therefore, this performance rule is inapplicable to any award of losses.

However, the inapplicability of obligatory regulation to losses appears most clearly from Article 328 of the Civil Code, which provides as follows:

$\langle\ldots\rangle$ where there are any circumstances clearly showing that... performance will not take place within the agreed time, the party required to provide consideration may... refuse to perform such obligation and claim for losses.

Let us assume that an agreement contains a provision stating that performance thereunder should be considered as a counter-obligation for the payment of any losses. In such an arrangement, any unilateral plea or claim for damages could undermine the ordinary performance of obligation and therefore also the principle of pacta sunt servanda, which is fundamental for a continental-type legal system.

\subsection{Applicability of chapter 23 "Methods of securing obligations" of the Civil Code}

How could Chapter 23 of the Civil Code be relied upon in a case concerning damages? In our opinion, it is most likely ${ }^{9}$ that it would be very difficult to apply. The main methods are penalty, pledge, lien, suretyship, deposit, guarantee and security payment.

Can pledges serve as security for claims for damages? Obviously not, because the size of the secured obligation is a material term of the agreement in this case (Article 339 of the Civil Code). The extent of damages is floating and dynamic, it may not be agreed on by the parties and is evaluative by its nature (Tirskaya 2003).

${ }^{8}$ See Clause 17 of RF Supreme Court Presidium Information Letter No. 120 dated 30 October 2007 titled "Review of the Practical Application of Commercial Courts of the Provisions of Chapter 24 of the Civil Code of the Russian Federation" where the RF Supreme Court states that "an obligation to compensate for losses is a monetary one".

9 "Most likely" because so far there have neither any final explanations of the supreme court nor amendments made to the Civil Code so far. 
Deposit and security payments are also difficult to apply to claims for damages for the same reasons. Therefore, despite all efforts made to reform the binding law, the security measures mainly for the recovery of damages require further clarification.

The most important method of securing an obligation is a penalty (Sebok 2009, 159), i. e., an amount of money payable for failure to perform or duly perform such obligation. A penalty is dependent on damages. If they constitute the value of infringement of an obligation, the penalty payable for a failure to pay them may, at a glance, be also envisaged in an agreement. It would be sufficient to specify that the party at fault should pay a penalty for the failure to reimburse for any damages incurred during a certain period of time so as to ensure that such a claim supports this universal legal remedy - in accordance with the parties' will as construed literally.

We are confident that a claim in respect of the aforementioned transfer of money would be illegal as the burden of losses has a different nature compared to obligations. A failure to perform obligations would allow invoking the substituting instrument of recovery of damages in an amount depending, first of all, on how such failure occurred. When an agreement is terminated or rescinded because of a material breach, the resulting losses are the costs of the violation plus anything not received or any future costs and become greater as a result of termination.

The concept of a penalty is commensurate with contractual damages (Benjamin 1960). Just as there can exist no title to a "right" rather than to a thing, there may be no legal substitute for losses resulting from a failure to pay damages. A court hearing any claims based on wrong legal logic would only bring chaos to the understanding of the purpose of losses, which are subject to judicial control and may not be based on any "exaggerated" unilateral estimates.

A lien as a legal remedy is equally incompatible with claims for damages. According to the second paragraph of Article 359 (1) of the Civil Code, business entities may enjoy a right of lien regarding property to be transferred as security for any claims arising from any obligations even if those obligations have no relation to the purchase price of the object or reimbursement of other expenses, or losses, connected thereto. If such obligations also include the legal category of damages, it would create room for arbitrary behaviour with a superficial perception of current losses constituting grounds for withholding any material properties.

In the Russian market for legal services, the legal actions brought against major manufacturers of expensive or luxury cars standout. After several accidents allegedly resulting from some defects in several of those cars, their wealthy and inventive owners instructed their "inquisitive" lawyers to raise claims against the manufacturers to refund them for the purchase prices paid for the cars, and after they got their money back they refused to return the cars to the manufacturers on the pretext that they should retain them in consideration for the "losses" since they created binding obligations secured by a lien in virtue of the law.

Although it is up to the courts to finally decide if any unilateral estimates are fair, they should meet specific constraints. Even more important is the uniform understanding by economic actors of the ties among the key matters of regulation, including, but not limited to, the idea that by no means would a unilateral declaration of losses automatically make its authors creditors nor would it permit them to use the whole arsenal of security measures in regard to any obligations. Otherwise, such a rarely used legal remedy (recovery of 
losses) would translate into an instrument of abuse and manipulation, thereby turning from a hat into a rabbit.

While the creditor may terminate the agreement, the underlying obligation will be secured by a suretyship. Article 363 of the Civil Code provides that "the guarantor shall be liable to the creditor to the same extent as the debtor, including payment of any accrued interest, any legal costs incurred to recover the debt and any other losses suffered by the creditor". However, the word "and" before "any" appears to constitute an unnecessary clarification here and should be replaced with "or". That is especially true given the fact that Article 363 is titled Liability of the Guarantor, even though the guarantor is bound by the agreement, acts for the debtor in performing his obligations and receives the same through subrogation of those and other losses.

\subsection{Application of chapter 25 "Liability for breach of obligations" of the Civil Code}

This section provides some examples of rules governing not only obligations. It is a duty rather than an obligation to avoid the effects of Article 404 Fault of the Creditor when the amount of any awarded losses decreases (Kotz 2017, 400) depending on the manifestation and extent of such fault. A claim to refrain from taking fault under Paragraph 6 of Article 393 is inconceivable as the claim doesn't pertain to the domain of obligations. A failure to refrain from taking a certain act is a failure to perform an obligation rather than a duty. Such required passivity should entail no classical liability for a failure to perform obligations. No claims to prevent and prohibit a fault act may have any legal grounds. That's why Article 404 should not belong to only "General" provisions on obligations.

However, the satisfactory technical approach implemented in some Articles of the Civil Code, such as Article 322 which deals with joint and several obligations, has a limited extent. As Article 322 covers duties (liability) in the event that there are several debtors or creditors for an obligation, we should take into consideration that this also mentions losses. On the other hand, Article 322 of the Civil Code deals with claims for an obligation, including those related to business, and says that such claims may arise from the terms of such obligation. Article 322 primarily governs matters of recovery of damages incurred as a result of a failure to perform an obligation, even if there are several beneficiaries and not only debtors. While it is titled Joint and Several Obligations, it also covers multiple creditors. Apparently, its title is not only inaccurate but completely wrong and needs to be replaced with the following: Joint and Several Liability and Rights to Claim Such Liability for a Failure to Perform Obligations, while Article 322 itself should be moved to Chapter 25 of the Civil Code.

Often, when one's trademarks are used and similar means of individualisation are applied in business, no obligations arise to take specific actions. While some people may argue that would constitute a tort, i. e., a damage caused to a property, the Civil Code no longer applies this term to intellectual property (Article 128 of the Civil Code). It is no longer a property, so it may not be subject to Chapter 59 of the Civil Code anymore as well. In that case, recovery of damages is prescribed as the main remedy because recovery in kind is impossible due to the fact that offending acts have been taken and, e.g., resulted in enrichment of the offender. 


\subsection{Chapter 26 "Termination of obligation" and legal effect of discharge of claims for losses}

Article 416 of the Civil Code "Termination of an obligation as non-performable" is inapplicable, since it cannot be impossible to make a payment, since money can always be accumulated through a loan, property sale, etc., and transferred in compensation for any damages incurred by the counterparty or creditor (Novitsky, Lunts 1950, 298).

The death of a debtor will not terminate the claim for losses against him, and that claim will be passed down to his successors ${ }^{10}$. A property being transferred by way of succession entails duties but not obligations arising not only from the relevant transaction, tort or unjustified enrichment, but also from other grounds, including the incurrence of losses ${ }^{11}$. The successors will bear that burden in proportion to their shares in succession.

When trying to determine the correlation between "duty" and "obligation", we see the effect of a natural differentiation of regulation as property transactions become more and more complex when there is a need to establish a regulatory framework for details, new massive manifestations and significant aspects of important legal categories.

However, novation should be explicitly applicable to damages recovery being transferred into obligations. We consider Article 414 (2) of the Civil Code to be obsolete. Novation and replacement of one obligation with another one extends to the so-called "additional obligations". Novation would lead to the same result of previous obligations being cancelled. As mentioned above, that term is sometimes used in the legal doctrine to describe the duty to incur somebody else's losses (Ioffe 2009, 263, 268). Certainly, the subsequent agreement may re-structure any disputable and controversial debt whatever (Kotz 2017, 400), and it's always called "novation".

Novation is not a transaction without consideration as it creates new claims as well as new obligations based on the idea of discount and, therefore, does not result in a gift, which is prohibited between commercial entities (Article 575 (1 (4)) of the Civil Code). Its correlation with Article 407 (2), which sets forth that an agreement may provide for an obligation to be terminated by the sole will of the debtor, can be emphasized since the same cannot be done with a claim for losses pursuant to Article 15 of the Civil Code permitting only reduction of liability.

\section{Conclusions}

The issues discussed in this paper are interesting, topical and deserve careful elaboration and discussion. Any further improvements to the regulatory framework on the recovery of losses must specify in more detail which particular concepts of binding law should also apply to claims for losses. The provisions contained in Chapter 24 as well as specific ones mentioned from Chapters 23, 26 of the Civil Code may be applied by reference, which should be expressly stated in the Civil Code in a way similar to the wording contained in Article 307.1 (3), which says that the general provisions concerning obliga-

10 A similar conclusion follows from the existing case law: see North-Caucasian District Commercial Court Order No. F08-6521/2019 dated 8 August 2019 in case No. A32-33226/2015, Far-Eastern District Commercial Court Order No. F03-1804/2019 dated 21 May 2019 in case No. A04-7886/2016, etc.

${ }^{11}$ See, e. g., the wording used in Article 48 of the Civil Code of the Russian Federation. 
tions should apply to the corporate legal relationships and the effects of invalidation of a transaction.

\section{References}

Agarkov, Mikhail M. 1940. "Obligation in soviet civil law". Uchenye trudy VIIuN 3, 70-79. Moscow, NKIu SSSR Publ. (In Russian)

Benjamin, Peter. 1960. "Penalties, liquidated damages and penal clauses in commercial contract: A comparative study of English and continental law". The International and Comparative Law Quarterly 9 (4): 600-627.

Frolova, Natal'ia M. 2017. "Prevention of an abuse of rights by the parties to legal relationships when an obligation is to be performed by a third party". Aktual'nye problemy rossiiskogo prava 8: $80-86$. (In Russian)

Hesselink, Martijn W. 2001. "The principles of European contract law: Some choices made by the Lando commission". Global Jurist Frontiers 1 (1) (4): 1-68. Accessed December 18, 2019. https://ssrn.com/ abstract $=1098869$.

Ioffe, Olimpiad S. 2009. Selected works on civil law. $3^{\text {rd }}$ ed. (revised). Moscow, Statut Publ. (In Russian)

Kotz, Hein. 2017. European contract law. $2^{\text {nd }}$ ed. London, Oxford University Press.

Koziol, Helmut. 2012. Basic questions of tort law from a Germanic perspective. Wien, Jan Sramek Verlag.

Krasyukov, Andrei V. 2012. "Tax obligation: Notion and features". Rossiiskaia iustitsiia 8: 12-14. (In Russian)

Meyer, Dmitrii I. 1997. Russian civil law. In 2 parts. Part 1. Moscow, Statut Publ. (In Russian)

Novitsky, Ivan B. 1993. Roman law. $4^{\text {th }}$ ed. (reprinted). Moscow, Assotsiatsiia "Gumanitarnoe znanie" Publ. (In Russian)

Novitsky, Ivan B., Lazar’ A. Lunts. 1950. General doctrine of obligations. Moscow, Iuridicheskaia literatura Publ. (In Russian)

Pechyonkina, Anzhelika A. 2007. "Obligation as a concept of tax law". Vestnik Omskogo universiteta. Ser. Pravo 3: 112-116. (In Russian)

Pobedonostsev, Konstantin P. 1896. The course of civil law. Part three: Agreements and obligations. St. Petersburg, Sinodal'naia tipografiia Publ. (In Russian)

Pokrovsky, Iosif A. 1998. Major problems in civil law. Moscow, Statut Publ. (In Russian)

Sadikov, Oleg N. 2009. Losses in civil law of the Russian Federation. Moscow, Statut Publ. (In Russian)

Sarbash, Sergei V. 2016. The elementary dogmatics of commitment. Moscow, Statut Publ. (In Russian)

Sebok, Anthony J. 2009. "Punitive damages in the United States". Punitive damages: Common law and civil law perspectives (Tort and insurance law. Vol. 25). Eds Helmut Koziol, Vanessa Wilcox, 155-196. Wien, Springer.

Sinaisky, Vasilii I. 2002. Russian civil law. Moscow, Statut Publ. (In Russian)

Tirskaya, Evgeniia V. 2003. "Obligation to compensate for losses as a cash debt resulting from violation of a civil obligation”. Sudebno-arbitrazhnaia praktika Moskovskogo regiona. Voprosy pravoprimeneniia 1-2: 34. (In Russian)

Yegorov, Evgenii V. 2016. "Payment made by a third party to a creditor beyond his will". Vestnik ekonomicheskogo pravosudiia 8: 150-160. (In Russian)

Received: March 10, 2020

Accepted: June 9, 2020

Authors' information:

Yuri E. Monastyrsky — Dr. Sci. in Law, Associate Professor; monastyrsky@mzs.ru

Vladimir N.Koval' - Dr. Sci. in Law, Professor; v.n.koval@sevsu.ru

Anatoliy A.Vlasov — Dr. Sci. in Law, Professor; prof.vlasov@mail.ru 